\title{
Status and distribution of the Endangered banteng Bos javanicus birmanicus in Vietnam: a conservation tragedy
}

\author{
Miguel Pedrono, Ha Minh Tuan, Philippe Chouteau and Frédéric Vallejo
}

\begin{abstract}
From January 2005 to December 2007 field surveys were conducted in the Central Highlands region of Vietnam to assess the status of banteng Bos javanicus birmanicus. The population of banteng was estimated to be 74-103. It has declined by at least $50 \%$ since the mid1990s and the species is likely to go extinct in Vietnam in the near future. Remaining herds are small, although recruitment still exists. Large portions of the species' range in the early 1990s are no longer occupied and the maximum area of occupancy of the species in Vietnam is c. 2,670 $\mathrm{km}^{2}$. Only five disconnected populations persist. The most important are in Yok Don National Park (30-44 individuals) and Ea So Nature Reserve (23-31). However, our surveys suggest that these populations are exposed to risks of disease outbreak and will only be viable if there is active management to facilitate recovery. Interviews carried out at the survey sites indicate that the status of banteng in Vietnam is determined by commercial poaching in response to demand for trophies. Future conservation actions need to target poor governance, the root cause of banteng decline, which precludes effective management of protected areas in Vietnam and places several species of large mammals at risk of extinction nationally.
\end{abstract}

Keywords Bos javanicus birmanicus, conservation status, distribution, poaching, protected areas, Vietnam

\section{Introduction}

$\mathrm{O}$ nce widely distributed in South-east Asia, the banteng Bos javanicus is now restricted to small fragmented populations. The number of individuals remaining in its native range is estimated to be $3,000-5,000$ and there has

Miguel Pedrono (Corresponding author) CIRAD, Campus International de Baillarguet, 34398 Montpellier Cedex 5, France, Wild Cattle Conservation Project, National Institute of Animal Husbandry, Thuy Phuong, Tu Liem, Hanoi, Vietnam, and CIRAD Representative Office, 3rd Floor, 35, Dien Bien Phu Street, Hanoi, Vietnam. E-mail pedrono@cirad.fr

Ha Minh Tuan Wild Cattle Conservation Project, National Institute of Animal Husbandry, Hanoi, Vietnam.

Philippe Chouteau Institute of Zoology, Chinese Academy of Sciences, Beijing, China.

FrÉDÉRIC VALlejo CIRAD, Campus International de Baillarguet, Montpellier, France, and Wild Cattle Conservation Project, National Institute of Animal Husbandry, Hanoi, Vietnam.

Received 11 March 2008. Revision requested 13 May 2008. Accepted 28 July 2008. been at least an $80 \%$ reduction in the global banteng range since the 1980 os (IUCN, 2008). Only seven populations with $>50$ banteng are known to remain in its native range: four in Java, two in Thailand and one in Cambodia. No population in the natural range exceeds 500 individuals (Phanthavong \& Santiapillai, 1991; Srikosamatara \& Suteethorn, 1995; Soriyun, 2001). As a consequence, the banteng is categorized as Endangered on the IUCN Red List (IUCN, 2008). Three subspecies of banteng are recognized, although further research is required to verify the taxonomy of this wild cattle species (Byers et al., 1995). The Java banteng Bos javanicus javanicus is confined to a few protected areas on the islands of Java and Bali, the Borneo banteng Bos javanicus lowi to the island of Borneo, and scattered, small populations of the Burma banteng Bos javanicus birmanicus persist in Myanmar, China, Thailand, Malaysia, Cambodia, Lao and Vietnam. The Burma banteng has been extirpated in India, Bangladesh, Brunei Darussalam and Peninsular Malaysia; it is considered the most threatened of the three subspecies (Heinen \& Srikosamatara, 1996). There is also a large non-native population of Java banteng in northern Australia, representing a potentially important reservoir for the native populations of this subspecies (Bradshaw et al., 2006).

The banteng is probably the ancestor of South-east Asian domestic cattle and its extinction would represent a major loss of genetic material for improving domestic cattle breeds. Successful banteng conservation remains elusive because the same forces that caused the probable extinction of the kouprey Bos sauveli in the 1980s or $1990 \mathrm{~s}$ are still operating (Hedges et al., 2007). External anthropogenic threats and intrinsic biological traits (e.g. low population densities, large home-range requirements and low reproduction rates; Cardillo et al., 2005) are driving banteng populations to extinction. But the underlying cause of banteng decline in South-east Asia is the growth of the human population (Sodhi et al., 2004). Impacts of human population density on biodiversity conservation have been demonstrated for several animal taxa (McKee et al., 2003). High human population densities lead to an increase in human pressure on ecosystems and undermine conservation activities. As a consequence, South-east Asia has experienced one of the highest rates of mammal population extinctions (Ceballos \& Ehrlich, 2002). In Vietnam the situation is particularly critical, with the highest human population density in South-east Asia and a rapidly expanding 
market economy. Vietnam experienced considerable changes in human density and land-use patterns after the North-South Vietnam War, and old-growth forests were lost at a rate of $14.6 \%$ year $^{-1}$ over 2000-2005 (Koh, 2007). This has resulted in large-scale habitat fragmentation and has rendered banteng more vulnerable to poaching. Large-scale internal transmigration towards the Central Highlands occurred after the war (Dak Lak People's Committee, 1994) and official resettlement programmes have increased human density in the areas of most suitable banteng habitat. A large portion of the banteng range in Vietnam is now subject to extreme levels of human disturbance and intervention.

A survey of banteng is a priority action for large mammal researchers in Vietnam (Duckworth \& Hedges, 1998). Understanding the current status of banteng populations in this densely populated country may help predict any future declines in the species' range and focus conservation efforts on the populations most at risk. Here we present information gathered during a study of the distribution and status of all wild cattle in Vietnam over 3 years. We report our findings for banteng by comparing the current distribution with that of 10-15 years ago (Duckworth \& Hedges, 1998) and summarize the factors that have determined the current precarious status of banteng in Vietnam.

\section{Study area}

The surveyed area covered 10 provinces in the Central Highlands region of Vietnam where banteng were known to have occurred in the early 1990s. This region can broadly be divided into three geographical zones: (1) the Kotum Plateau and southern Annamite mountains in the north, (2) the flat central plateau of Gia Lai and Dak Lak, and (3) the $\mathrm{Da}$ Lat Plateau and southern mountains. These areas have a subtropical monsoon climate. The south-west monsoon winds of June-November bring rains and occasional typhoons to the eastern slopes of the mountains. In December-April there is a drier period that is characterized by winds of the north-east monsoon. The survey focused on Yok Don National Park $\left(1,155 \mathrm{~km}^{2}\right)$, Ea So Nature Reserve $\left(220 \mathrm{~km}^{2}\right)$, Cat Tien National Park $\left(719 \mathrm{~km}^{2}\right)$, Vinh Cuu Nature Reserve $\left(538 \mathrm{~km}^{2}\right)$ and several state forest enterprises.

The vegetation of the Central Highlands consists primarily of lowland deciduous dipterocarp forest dominated by Dipterocarpus obtusifolius, Dipterocarpus tuberculatus, Shorea obtusa and Shorea siamensis, and highland evergreen forest characterized by Lagerstroemia calyculata, Shorea cochinchinensis and Anisoptera scaphula. Bamboos such as Bambusa balcooa are common in the evergreen forest, particularly as colonizers of open areas after disturbance. Few patches of primary forest remain because of extensive selective logging and forest replacement by plantations. This region also suffered from the spraying of defoliants during the NorthSouth Vietnam War (Stellman et al., 2003), resulting in extensive degradation. Moreover, because of the influx of settlers from northern Vietnam much of the original forest cover of the Central Highlands has been cleared to make way for settlements, plantations and agriculture.

\section{Methods}

Survey areas were chosen based on both historical records and interviews with local villagers. Surveys were carried out from January 2005 to December 2007, mainly in the dry season (October-June) when field access is possible. Surveys were conducted on foot, motorcycle and, in Yok Don National Park, by elephant, both during the day and night. We searched for all species of wild cattle (B. javanicus, gaur Bos gaurus and wild water buffalo Bubalus arnee) with the exception of the saola Pseudoryx nghetinhensis, which generally occurs in more rocky areas. At least two surveys were conducted per site, and the data collected at each site were pooled, with the assumption that there was no significant change in population during the study period. The number of surveyors was $3^{-8}$, including field rangers and local guides. The survey team was generally split into $2-3$ groups operating simultaneously in different parts of the surveyed areas. There was at least one experienced observer in each group.

The extremely low density of banteng in Vietnam precludes the use of line transect surveys. The most practical way of estimating banteng distribution and abundance was to search for signs of activity, especially tracks and dung, in likely areas. Searches focused on salt licks, open grasslands, wetland margins, watercourses, ridges and large mammal trails. Coordinates of only fresh tracks and dung $\left(<_{1}\right.$ week old) were recorded. Banteng tracks are on average narrower than gaur tracks (Wharton, 1957; Prayurasiddhi, 1997). In some cases, however, the assignment of tracks to banteng or gaur was not possible, and in such circumstances they were not recorded. Although there is no notable difference between dung of banteng and gaur, the presence of tracks near the dung was used to pre-identify the species of origin. Dung samples were then stored in both alcohol and RNALater, a stabilization reagent, for later analysis. Species assignment was based on the analysis of a cytochrome $b$ gene fragment with several species-specific diagnostic nucleotides (Rivière-Dobigny et al., 2009). The fragment sequenced corresponds to positions 867-1140 in the cytochrome $b$ gene of domestic cattle Bos taurus. DNA amplifications were performed using the following primers: L15612: 5'-CGATCA-ATY-CCY-AAY-AAA-CTA-GG-3' and H15915 (reverse): -TCT-CCA-TTT-CTG-GTT-TAC-AAG-AC-3' (Hassanin et al., 2006). Although banteng sometimes forage in the same grazing areas as domestic cattle (i.e. in Ea So Nature Reserve, Vinh Cuu Nature Reserve and Krong Trai Nature Reserve) and produce similar-sized and shaped tracks, the molecular approach we used facilitated unambiguous identification. Such an approach proved to be more 
effective than camera trapping, which was abandoned early in the study.

This molecular approach was not, however, effective for genotyping field samples to allow the minimum population size and sex ratio to be determined. Amplification success rate of microsatellites from faecal DNA was low. High temperatures in central Vietnam seem to negatively affect the conservation of microsatellites before the dung is collected (Wehausen et al., 2004). It was also not possible to estimate population sizes from dung density because of difficulties in estimating defecation and dung decay rates (Wiles, 1980). Thus, we used the difference in size of tracks that allowed identification of individuals when the herd was small. It was difficult, however, to estimate population size for large herds using this approach. In such cases the population size reported was therefore based on direct observations, mainly from forest rangers and local villagers (i.e. former or present hunters).

Banteng were also occasionally observed by our survey teams, largely opportunistically and during the day. Nocturnal watches were occasionally carried out in places where abundant activity signs were recorded during the day but successful observations were few, presumably because of the shy behaviour of banteng (caused by high levels of human disturbance and poaching). However, such high levels of human presence offered opportunities for fruitful interviews with local people (all the herds of banteng that were recorded from tracks had been observed several times by local people). We interviewed local villagers and forest officials about the past and current occurrence of banteng. Semi-structured discussions focused on banteng and herd numbers, locations and dates of observations, threats and poaching rates. Some questions were worded differently and repeated to cross-check answers, especially those concerning the size of specific herds. Illustrations were produced at the end of the interviews to confirm species' identities when confusion existed between descriptions of banteng and gaur. Hunting trophies of wild cattle were also examined whenever possible. Duckworth \& Hedges (1998), who used survey reports and articles, complemented by interviews with local people and government staff, to assess the status of banteng in Indo-China, were our source for data on historical banteng populations.

\section{Results}

The banteng range in Vietnam now extends from Chu Prong District in the north to Vinh Cuu Nature Reserve in the south (Fig. 1). Banteng were documented at six of the 18 localities surveyed. These localities represent five disconnected populations (Chu Prong, Yok Don, Ea So, Krong Trai and Dong Phu), separated by highly modified areas. In Chu Mom Ray, Dak R'Lap, Nam Nung, Ta Dung, Bu Dang, Nam Cat Tien, Bi Doup Nui Ba, Cat Loc, Nui Ong and Bu
Gia Map, the banteng is now locally extinct, although it was still present there in the early 1990 os (Fig. 1, Table 1). Local villagers told us that banteng were present until the early 1990 s in all these sites but that they were poached to extinction within the last decade. We estimate the species' area of occupancy (sensu IUCN, 2008) in Vietnam to be c. $2,670 \mathrm{~km}^{2}$ in total, with c. $1,433 \mathrm{~km}^{2}$ in Dak Lak Province, c. $431 \mathrm{~km}^{2}$ in Gia Lai Province, c. $228 \mathrm{~km}^{2}$ in Phu Yen Province and c. $578 \mathrm{~km}^{2}$ on the border between Binh Phuoc and Dong Nai provinces. All these areas appear to be encroached by human activities. There is no evidence that banteng survive in other provinces (Table 1). Extirpation of herds has resulted in the loss of at least $52 \%$ of the 1990 os range of the species in Vietnam. Three populations are inside protected areas (Yok Don National Park, Ea So and Krong Trai Nature Reserves) and two outside (Chu Prong and Dong Phu districts), and c. $82 \%$ of the total number of individuals occur within a protected area and $18 \%$ outside.

We estimate that the total number of banteng in Vietnam is $74-103$ (Table 1), with no population $>50$; the last population of this size occurred in Yok Don National Park, which previously comprised a smaller Yok Don National Park and Ea Sup District, until the early 1990s. Yok Don is still the largest population of banteng in Vietnam but it has declined to 30-44, surviving over an area of c. 1,155 $\mathrm{km}^{2}$. The second largest population is in Ea So Nature Reserve, where we estimate that 23-31 banteng survive in an area of c. $278 \mathrm{~km}^{2}$. The populations of Chu Prong District, Krong Trai Nature Reserve and Dong Phu District have been reduced to a few individuals (Table 1). Calves or juveniles are present in all five remaining populations, indicating that some recruitment still exists.

The populations of banteng in Vietnam have suffered major declines, essentially because of poaching. A large number of banteng have been poached for commercial purposes since the mid 1990 s and poaching shows no signs of abating. We documented the deaths of 13 individuals during 2002-2006, including 11 in protected areas (Table 2). This is a minimum estimate; local villagers and officials from the Forest Protection Department are often reluctant to report poaching of large mammals such as banteng. Poaching is for trophies, comprising the head and/or horns, which are sold for c. USD 900. Other body parts do not appear to be sold. Demand from wealthy Vietnamese living in urban areas drives poaching. Poachers use cable snares or guns. Army personnel stationed at the border between Vietnam and Cambodia (i.e. in Yok Don National Park and Chu Prong District) also poach for subsistence food needs. The number of herds lost has been similar across provinces and habitat types, although intensive poaching is particularly severe where the largest populations of banteng still exist (Table 2).

In all the areas surveyed, including protected areas, we recorded other human activities, such as fishing, wood-resin exploitation, wood cutting, forest fires, shifting cultivation 


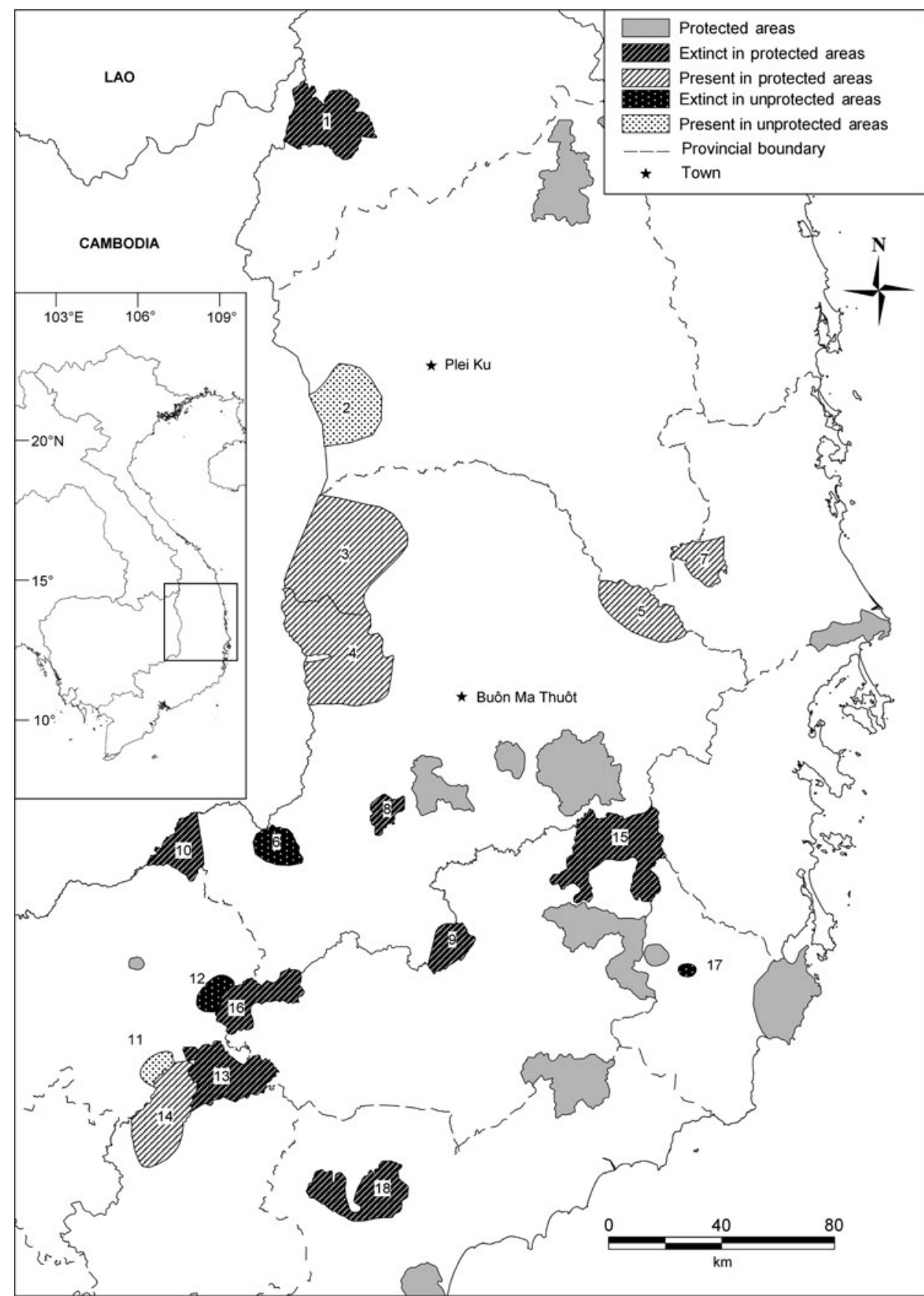

Fig. 1 Current and past range of banteng in Vietnam. Numbers indicate named sites in Table 1. The rectangle on the inset indicates the location of the main figure in Vietnam.

and livestock grazing. In Ea So, Yok Don, Krong Trai and Vinh Cuu the grasslands are generally exploited by banteng during the night and by domestic cattle during the day. The number of domestic cattle around Ea So Nature Reserve has approximately doubled in the last 5 years and most are severely affected by both foot-and-mouth disease and bovine pasteurellosis. The management board of Ea So Nature Reserve is even breeding its own herd of 115 domestic cattle inside the Reserve for economic profit. The rate of forest clearing by migrants from northern Vietnam is also in- creasing in Chu Prong and Dong Phu districts, leading to loss of habitat and habitat fragmentation. Road construction is affecting all the places surveyed by encouraging human settlement and thereby increasing human pressures.

\section{Discussion}

In the 1960 s banteng were still widespread in central Vietnam but intensively hunted (Wharton, 1968). In 1990-1993 the total population in Vietnam was estimated to be $200-300$ 
TABLE 1 Previous (Duckworth \& Hedges, 1998) and current estimates (this study) of banteng populations at 18 locations inVietnam. Numbered locations refer to Fig. 1.

\begin{tabular}{|c|c|c|c|c|c|}
\hline Location $^{1}$ & Province & $\begin{array}{l}\text { Habitat } \\
\text { area }\left(\mathrm{km}^{2}\right)\end{array}$ & $\begin{array}{l}\text { Previous status } \\
\text { or estimate }\end{array}$ & $\begin{array}{l}\text { Status or } \\
\text { estimate in } 2005-2007^{2}\end{array}$ & $\begin{array}{l}\text { Survey-hours } \\
\text { in } \\
2005-2007\end{array}$ \\
\hline 1, Chu Mom Ray NP & Kon Tum & 566 & Present (early 1990s) & Extinct & 17.5 \\
\hline 2, Chu Prong District & Gia Lai & 431 & Present & $7-12,1$ herd & 22.0 \\
\hline 3, Ea Sup/north Yok Don NP & Dak Lak & 573 & $70-90(1995)$ & $13-19,2-3$ herds & 98.0 \\
\hline 4, South Yok Don NP & Dak Lak & 582 & $35-45(1993)$ & $17-25,3-4$ herds & 166.5 \\
\hline 5 , Ea So NR & Dak Lak & 278 & $>17(1997)$ & $23-31,4-6$ herds & 154.0 \\
\hline 6, Dak R'Lap District & Dak Nong & 57 & $8(1993)$ & Extinct & 21.0 \\
\hline 7, Krong Trai NR & Phu Yen & 228 & $15-20(1997)$ & $8-10,2$ herds & 32.0 \\
\hline 8, Nam Nung NR & Dak Nong & 108 & Present (1993) & Extinct & 19.2 \\
\hline 9, Ta Dung NR & Dak Nong & 214 & Present (early 1990s) & Extinct & 38.5 \\
\hline 10, Bu Gia Map NP & Binh Phuoc & 223 & Present (early 1990s) & Extinct & 110.0 \\
\hline 11, Dong Phu District & Binh Phuoc & 40 & Present & 6,1 herd & 89.5 \\
\hline 12, Bu Dang District & Binh Phuoc & 48 & Present (early 1990s) & Extinct & 32.0 \\
\hline $\begin{array}{l}\text { 13, Nam Cat Tien/Cat } \\
\text { Tien NP }\end{array}$ & Dong Nai & 383 & Present (1998) & Extinct & 458.0 \\
\hline 14, Vinh Cuu NR & Dong Nai & 538 & Present & Same herd as location 11 & 230.6 \\
\hline 15, Bi Doup Nui Ba NP & Lam Dong & 640 & Present (early 1990s) & Extinct & 10.5 \\
\hline 16, Cat Loc/Cat Tien NP & Lam Dong & 306 & Present (1995) & Extinct & 182.5 \\
\hline 17, Ninh Son District & Ninh Thuan & 26 & $40-45(1998)$ & Extinct & 8.0 \\
\hline 18 , Nui Ong NR & Binh Thuan & 370 & $10(1994)$ & Extinct & 12.8 \\
\hline
\end{tabular}

${ }^{1}$ These 18 localities represent 16 distinct populations (north-south Yok Don NP and Dong Phu District-Vinh Cuu NR each constitute single populations). NP, National Park; NR, Nature Reserve.

${ }^{2}$ Minimum and maximum population sizes were estimated when it was not possible to determine the exact number of individuals; the values are the mean minimum and maximum population sizes from all the surveys in the particular area

(Le, 1995). An estimate in 1998 derived from interviews suggested that the population was no more than $170-195$ individuals, with a strong ongoing decline (Do \& Le, 1998). Our estimate for 2004-2007 is yet lower (74-103), persisting in a few areas of lower human pressures as small widely dispersed herds. This population has experienced a decline in number of $>50 \%$ since the mid 1990s. Eleven of the 16 populations that were probably still present in the mid 1990s are now extinct or have dropped to levels so low that local villagers and our survey team failed to encounter any individuals. None of the five remaining populations will be able to survive without management to facilitate recovery.

The average herd size of five that we observed during the dry season is similar to the herd size reported for this species in densely vegetated areas, which is typically $<8$ (Halder, 1973, 1976). However, herd size was expected to be higher than this average figure in areas such as Yok Don

TABLE 2 Reported banteng deaths during 2002-2006 in Vietnam based on interviews with forest rangers and national press releases. Numbered locations refer to Fig. 1.

\begin{tabular}{llll}
\hline Year & Location $^{*}$ & Main habitat type & Details \\
\hline 2002 & 7, Krong Trai NR & Semi-evergreen forest & 1 adult caught by a snare \\
2002 & 11, Dong Phu District & Semi-evergreen forest & 1 juvenile caught by a snare \\
2003 & 5, Ea So NR & Dry dipterocarp forest & 1 adult shot \\
2004 & 3, North Yok Don NP & Dry dipterocarp forest & 1 adult caught by a snare \\
2004 & 5, Ea So NR & Dry dipterocarp forest & 1 adult caught by a snare \\
2005 & 4, South Yok Don NP & Dry dipterocarp forest & 1 adult shot \\
2005 & 5, Ea So NR & Dry dipterocarp forest & 2 adults caught by a snare \\
2006 & 2, Chu Prong District & Dry dipterocarp forest & 1 trophy of banteng seized \\
2006 & 3, North Yok Don NP & Dry dipterocarp forest & 1 juvenile found dead \\
2006 & 5, Ea So NR & Dry dipterocarp forest & 1 trophy of banteng seized \\
2006 & 7, Krong Trai NR & Semi-evergreen forest & 2 adults caught by snares \\
\hline
\end{tabular}

${ }^{*}$ NP, National Park; NR, Natural Reserve 
National Park or Ea So Nature Reserve where the vegetation is dominated by open dry dipterocarp forests with extensive grasslands (Wharton, 1957, 1968). It is unlikely that estimates would be much higher during the rainy season when herds of banteng typically aggregate (Wharton, 1968; Srikosamatara \& Steethorn, 1995) because of the small number of herds. Sympatric populations of gaur live in all the locations where banteng are still extant in Vietnam. Although at a national level gaur largely outnumber banteng, banteng are more abundant in the open dry dipterocarp forests of Yok Don and Ea So protected areas, probably because of habitat preferences.

Local villagers did not report any sudden declines in banteng populations since the mid 1990 os that could have been attributed to disease outbreaks. More likely, intense poaching pressure has depleted or extirpated populations. If poaching pressures remain high, the species is likely to go extinct in Vietnam; the Yok Don population is likely to be the last to survive because of its larger size and connection with other populations. Forest clearing can benefit banteng as it provides additional grazing, and we found that banteng tend to move into open areas to feed at night. Thus, patterns of shifting cultivation and the associated formation of secondary forest in South-east Asia have historically provided banteng with suitable habitat (Wharton, 1968; Sodhi \& Brook, 2006).

Even though the banteng is legally protected in Vietnam little attention is paid to the implementation of wildlife protection laws, and traffic in banteng and gaur trophies is common (Nguyen, 2009). Such trophies, which are thought to bring luck to the owners, can be found for sale in shops and are exhibited in many houses, hotels and restaurants without any apparent threat of prosecution. Smugglers are aware that any fines imposed will be outweighed by the financial rewards and that growing economic wealth in urban areas is fuelling demand.

Although the direct cause of the collapse of banteng populations in the sites surveyed is poaching, the underlying factor that allows poaching to continue unabated is poor governance, as has already been reported in Vietnam (Kemp et al., 1997) and elsewhere (Smith et al., 2003). Nearly all the herds of banteng in Vietnam reside inside protected areas (Table 1) but most of these are not managed in practice, despite high protected area staffing levels (e.g. one ranger per 7.7 and $5.6 \mathrm{~km}^{2}$ in Yok Don and Cat Tien National Parks, respecively). During c. 1,703 survey-hours over 3 years we never met any ranger patrols in the protected areas surveyed. The protected areas that we surveyed appear to be 'paper parks', with inadequate and unmotivated staff on low government pay scales, tacitly accepted corruption of officials and high political patronage. As a consequence, no part of the banteng's extent of occurrence in Vietnam is effectively protected from poaching.
Management policies of various government bodies are often incompatible with the objectives of protected areas. This includes the construction of roads and dams in Ea So and Krong Trai Nature Reserves, and Yok Don and Bu Gia Map National Parks. Many protected areas are too small to sustain large mammal populations or too heavily degraded to satisfy conservation goals (Tordoff et al., 2004). Such small areas do not always include the wet and dry season ranges necessary to sustain a viable population of banteng. All these issues are compounded by the prevailing view of government officials who regard ethnic minority communities as a problem for conservation rather than as potential conservationists (Sheil \& Lawrence, 2004). Moreover, few rangers come from local ethnic minorities; most are from northern Vietnam and have no practical field experience (McElwee, 2000, 2002).

We recommend enforcement of the legislation on wildlife hunting and trading in Vietnam to stem poaching of banteng. Recognizing this problem is the first step to addressing it (Smith \& Walpole, 2005). It is essential that motivated rangers patrol protected areas to deter poachers and destroy snares. Incentive systems rewarding antipoaching activities should be implemented, and it may be better to have fewer well-paid and capable rangers than many low-paid ones. Local people's concerns should not be ignored in the development of future protected area policies; ethnic minorities and Kinh (the dominant ethnic group) rangers need to cooperate to protect wildlife (Steinmetz et al., 2006). The presence of domestic cattle at many banteng grazing sites poses a risk of transmission and outbreak of infectious disease in banteng. The vaccination of domestic cattle in the periphery of protected areas against foot-and-mouth disease and bovine pasteurellosis would be a short-term measure to avoid an epizooty in banteng. Livestock fences could be used to confine domestic cattle outside certain protected areas to avoid such epizooties and to preclude genetic introgression and foraging competition. Such fences, built by the Wild Cattle Conservation Project on $4.3 \mathrm{~km}$ of the border of Cat Tien National Park, have already limited contact between the herds of gaur inside the Park and adjacent domestic cattle.

Conservation efforts for the banteng in Vietnam should prioritize Yok Don National Park, the largest protected area of Vietnam, which supports the main population of banteng in extensive dry dipterocarp forest containing seasonal pools, the optimal habitat for wild cattle. To the west, Yok Don National Park borders Srepok Wilderness Area in Cambodia. This has the largest population of wild cattle in the Indo-Chinese Peninsula (Desai \& Vuthy, 1996), with the potential to repopulate Yok Don National Park with banteng, gaur and wild water buffalo. That banteng move across the Vietnam-Cambodia border can explain why other recent surveys of banteng in Yok Don National Park report much lower population size estimates (Nguyen, 
2009). The banteng population of Ea So Nature Reserve is the second largest population in Vietnam and effective control of poaching is required to allow recovery. Banteng recovered rapidly after large population decreases in Java (S. Pudyatmoko, pers. comm.). However, the expansion of settlements in this region continues and a hydroelectric construction project is currently affecting the north of the Reserve.

Because of regional distribution patterns surveys of banteng need to be extended to Lao and Cambodia. As the lowest human density in the Indo-China Peninsula occurs along the border between these countries and Vietnam, significant populations of banteng still live there. Coordinated action between states is needed, especially to control the trade of wildlife trophies. Extinction of large herbivores such as the banteng from Indo-Chinese forests could induce major changes in regional ecosystem structure and lead to further extinctions (van Wieren \& Bakker, 2007). A cooperation agreement with neighbouring countries would allow sharing of information, development of regional population estimates, and facilitate development and implementation of a regional conservation strategy for banteng and other wild cattle. To achieve this a regional strategic conservation planning workshop was convened in June 2008 in Vietnam by the IUCN/SSC Asian Wild Cattle Specialist Group and The Wild Cattle Conservation Project. Delegates from 11 South-east Asian countries, comprising academics, experts, policy makers, NGOs and government officials, agreed to a regional conservation strategy for wild cattle and buffaloes. The main actions identified in the strategy included strengthened enforcement of legislation on wildlife hunting and trade, together with measures to improve the effectiveness of protected areas and to manage interactions with domestic livestock to reduce disease transmission and interbreeding.

\section{Acknowledgements}

We thank Bach Thanh Hai, Cécile Berthouly, Philippe Chardonnet, Alison Clausen, Rémi Gouin, Le Quang Nam, Jean-Charles Maillard, Johan Michaux, François Monicat, Nguyen Hoang Hao, Nguyen Huynh Thuat, Nguyen Thi Hanh, Nguyen Van Cuong, Nguyen Van Khanh, Nguyen Van Thanh, Ghislain Rieb, Pham Huu Khanh, Tran Thuc Quyet, Tran Van Thanh, Marie-Noel de Visscher and Vu Chi Cuong for their efforts in the Wild Cattle Conservation Project in Vietnam. We also thank the local villagers who took part in the field surveys and interviews. Funding for the project was provided primarily by the French Global Environment Facility. The Ministry of Agriculture and Rural Development granted us special permission to survey the restricted frontier areas with Lao and Cambodia. We also thank two anonymous reviewers for their helpful comments.

\section{References}

Bradshaw, C.J.A., Isagi, Y., Kaneko, S., Bowman, D.M.J.S. \& B RоOK, B.W. (2006) Conservation value of non-native banteng in northern Australia. Conservation Biology, 20, 1306-1311.

Byers, O., Hedges, S. \& Seal, U.S. (1995) Asian Wild Cattle Conservation Assessment and Management Plan Workshop. IUCN/Species Survival Commission Conservation Breeding Specialist Group, Apple Valley, USA.

Cardillo, M., Mace, G.M., Jones, K.E., Bielby, J., BinindaEmonds, O.R., Sechrest, W. et al. (2005) Multiple causes of high extinction risk in large mammal species. Science, 309, 12391241.

Ceballos, G. \& Ehrlich, P.R. (2002) Mammal population losses and the extinction crisis. Science, 296, 904-907.

Dak Lak People's Committee (1994) Socio-Economic Planning in Dak Lak: 1994-2010. Dak Lak People's Committee, Buôn Ma Thuôt, Vietnam. [In Vietnamese]

Desai, A. \& Vuthy, L. (1996) Status and Distribution of Large Mammals in Eastern Cambodia: Results of the First Foot Surveys in Mondulkiri and Rattanakiri Provinces. IUCN, FFI \& WWF Large Mammal Conservation Project, Phnom Penh, Cambodia.

Do, T. \& Le, T.T. (1998) Project for Planning, Conservation and Development for Endangered Species in Vietnam. FIPI, Hanoi, Vietnam. [In Vietnamese]

Duckworth, J.W. \& Hedges, S. (1998) A Review of the Status of Tiger, Asian Elephant, Gaur, and Banteng in Viet Nam, Lao, Cambodia, and Yunnan (China), with Recommendations for Future Conservation Action. WWF Indochina Programme, Hanoi, Vietnam.

HALDER, U. (1973) Ecological aspects of social organization in banteng (Bos javanicus) and feral buffalo (Bubalus bubalis) in Java. Proceedings Congress of International Union of Game Biologists, 11, 159-164.

Halder, U. (1976) Okologie und Verhalten des Banteng (Bos javanicus) in Java. Eine Feldstudie. Mammalia Depicta, 10, $1-124$.

Hassanin, A., Ropiquet, A., Cornette, R., Tranier, M., Pferrer, P., Candegabe, P. \& Lemaire, M. (2006) Has the kouprey (Bos sauveli Urbain, 1937) been domesticated in Cambodia? Comptes Rendus Biologies, 329, 124-135.

Hedges, S., Groves, C.P., Duckworth, J.W., Meijaard, E., Timmins, R.J. \& Burton, J.A. (2007) Was the kouprey a feral hybrid? A response to Galbreath et al. (2006). Journal of Zoology, $271,242-245$.

Heinen, J.T. \& Srikosamatara, S. (1996) Status and protection of Asian wild cattle and buffalo. Conservation Biology, 10, 931-934.

IUCN (2008) 2008 IUCN Red List of Threatened Species. IUCN, Gland, Switzerland. Http://www.redlist.org [accessed 12 June 2009].

Kemp, N., Dilger, M., Burgess, N. \& Chu Van, D. (1997) The saola Pseudoryx nghetinhensis in Vietnam-new information on distribution and habitat preferences, and conservation needs. Oryx, 31, 37-44.

KoH, L.P. (2007) Impending disaster or sliver of hope for South-east Asian forests? The devil may lie in the details. Biodiversity and Conservation, 16, 3935-3938.

LE, V.K. (1995) The status of wild cattle and their conservation in Vietnam. In Asian Wild Cattle Conservation Assessment and Management Plan Workshop (eds O. Byers, S. Hedges \& U.S. Seal), pp. 121-131. IUCN/Species Survival Commission Conservation Breeding Specialist Group, Apple Valley, USA.

McElwee, P. (2000) Parks or People: Exploring Alternative Explanations for Protected Area Development in Vietnam. 
Conservation and Sustainable Development Comparative Perspectives Workshop. Yale University, New Haven, USA. Http:// research.yale.edu/CCR/environment/papers/mcelwee.pdf [accessed 10 July 2009].

McElwee, P. (2002) Lost worlds and local people: protected areas development in Vietnam. In Conservation and Indigenous Mobile Peoples: Displacement, Forced Settlement, and Sustainable Development (eds D. Chatty \& M. Colchester), pp. 312-329. Berghahn Press, Oxford, UK.

McKee, J.K., Sciulli, P.W., Foose, C.D. \& Waite, T.A. (2003) Forecasting global biodiversity threats associated with human population growth. Biological Conservation, 115, 161-164.

NGUYen, M.H. (2009) The status of Vulnerable gaur Bos gaurus and Endangered banteng Bos javanicus in Ea So Nature Reserve and Yok Don and Cat Tien National Parks, Vietnam. Oryx, 43, 129135.

Phanthavong, B. \& Santiapillai, C. (1991) Status, distribution and conservation of wild cattle in Laos. Asian Wild Cattle Specialist Group Newsletter, 4, 3-15.

Prayurasiddhi, T. (1997) The ecological separation of gaur (Bos gaurus) and banteng (Bos javanicus) in Huai Kha Khaeng Wildlife Sanctuary, Thailand. PhD thesis, University of Minnesota, Crookston, USA.

Rivière-Dobigny, T., Pham, D.L., Le, Q.N., Maillard, J.C. \& Michaux, J. (2009) Species identification, molecular sexing and genotyping using non-invasive approaches in two wild bovid species: Bos gaurus and Bos javanicus. Zoo Biology, 28, 127-136.

Sheil, D. \& Lawrence, A. (2004) Tropical biologists, local people and conservation: new opportunities for collaboration. Trends in Ecology \& Evolution, 19, 634-638.

Smith, R.J., Muir, R.D.J., Walpole, M.J., Balmford, A. \& Leader-Williams, N. (2003) Governance and the loss of biodiversity. Nature, 426, 67-70.

Smith, R.J. \& Walpole, M.J. (2005) Should conservationists pay more attention to corruption? Oryx, 39, 251-256.

Sodhi, N.S. \& Brook, B.W. (2006) South-east Asian Biodiversity in Crisis. Cambridge University Press, Cambridge, UK.

Sodhi, N.S., Koh, L.P., Brook, B.W. \& NG, P.K.L. (2004) Southeast Asian biodiversity: an impending disaster. Trends in Ecology \& Evolution, 19, 654-660.

Soriyun, M. (2001) Status and distribution of wild cattle in Cambodia. Tigerpaper, 28, 9-14.

Srikosamatara, S. \& Suteethorn, V. (1995) Populations of gaur and banteng and their management in Thailand. The Natural History Bulletin of the Siam Society, 43, 55-83.
Steinmetz, R., Chutipong, W. \& Seuaturien, N. (2006) Collaborating to conserve large mammals in South-east Asia. Conservation Biology, 20, 1391-1401.

Stellman, J.M., Stellman, S.D., Christian, R., Weber, T. \& Tomasallo, C. (2003) The extent and patterns of usage of Agent Orange and other herbicides in Vietnam. Nature, 422, $681-687$.

Tordoff, A.W., Tran, Q.B., Nguyen, D.T. \& Le, M.H. (eds) (2004) Sourcebook of Existing and Proposed Protected Areas in Vietnam, 2nd edition. BirdLife International Indochina and the Ministry of Agriculture and Rural Development, Hanoi, Vietnam.

VAN Wieren, S. \& BAKKer, J. (2007) The impact of browsing and grazing herbivores on biodiversity. In The Ecology of Browsing and Grazing (eds I.J. Gordon \& H.T. Prins), pp. 263-292. SpringerVerlag, Berlin, Germany.

Wehausen, J.D., Ramey, R.R. \& Epps, C.W. (2004) Experiments in DNA extraction and PCR amplification from bighorn sheep faeces: the importance of DNA extraction method. Journal of Heredity, 95, 503-509.

Wharton, C.H. (1957) An Ecological Study of the Kouprey, Novibos sauveli (Urbain). Institute of Science and Technology, Manila, Philippines.

Wharton, C.H. (1968) Man, fire and wild cattle in South-east Asia. Proceedings Annual Tall Timbers Fire Ecology Conference, 8, 107167.

WiLES, G.J. (1980) Faeces deterioration rates of four wild ungulates in Thailand. The Natural History Bulletin of the Siam Society, 28, 121134 .

\section{Biographical sketches}

Miguel Pedrono has been the coordinator of the Wild Cattle Conservation Project in Vietnam since 2004. As part of this project and through his membership of the Asian Wild Cattle Specialist Group of the IUCN/Species Survival Commission, he is developing a regional conservation strategy for banteng and gaur. $\mathrm{H}_{\mathrm{A}}$ MINH TUAN is a wildlife veterinarian whose main area of study is the quantification of the risks of transmission of infectious disease between wild and domestic cattle in Vietnam. Philippe Chouteau has a particular interest in the management of large mammals and birds. FRÉDÉRIC VALLEJO carries out research on the viability of populations of wild cattle in Vietnam. He is currently investigating how the dynamics of these populations are influenced by poaching pressure. 